\title{
Article \\ Food Purchase Behavior during The First Wave of COVID-19: The Case of Hungary
}

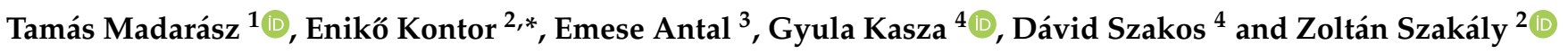 \\ 1 Institute of Sports Economics and Management, Faculty of Economics and Business, University of Debrecen, \\ Böszörményi Street 138, H-4032 Debrecen, Hungary; madarasz.tamas@econ.unideb.hu \\ 2 Institute of Marketing and Commerce, Faculty of Economics and Business, University of Debrecen, \\ Böszörményi Street 138, H-4032 Debrecen, Hungary; szakaly.zoltan@econ.unideb.hu \\ 3 Hungarian Platform of Diet, Physical Activity and Health, Andrássy Street 61, H-1062 Budapest, Hungary; \\ diet.emese.antal@gmail.com \\ 4 National Food Chain Safety Office, Kitaibel Pál Street 1, H-1024 Budapest, Hungary; \\ kaszagy@nebih.gov.hu (G.K.); kszakosd@nebih.gov.hu (D.S.) \\ * Correspondence: kontor.eniko@econ.unideb.hu
}

\section{check for}

updates

Citation: Madarász, T.; Kontor, E.;

Antal, E.; Kasza, G.; Szakos, D.;

Szakály, Z. Food Purchase Behavior during The First Wave of COVID-19: The Case of Hungary. Int. J. Environ. Res. Public Health 2022, 19, 872.

https://doi.org/10.3390/ ijerph19020872

Academic Editors: Isaac Ashkenazi, Carmit Rapaport and Paul

B. Tchounwou

Received: 18 December 2021

Accepted: 11 January 2022

Published: 13 January 2022

Publisher's Note: MDPI stays neutral with regard to jurisdictional claims in published maps and institutional affiliations.

Copyright: (C) 2022 by the authors. Licensee MDPI, Basel, Switzerland. This article is an open access article distributed under the terms and conditions of the Creative Commons Attribution (CC BY) license (https:// creativecommons.org/licenses/by/ $4.0 /)$.

\begin{abstract}
Coronavirus disease (SARSCoV-2) appeared in 2019 was confirmed as pandemic by the WHO on 11 March 2020. Stay-at-home order had an impact on consumers' food purchase habits, as people around the world were able to leave their homes solely in extremely severe or urgent cases. In our research, we delve into the impact of COVID-19 pandemic on consumers' food purchase habits. The research involved 3000 consumers during the first wave of coronavirus. The sample represents the Hungarian population by gender and age. To achieve the research goals, we applied multivariate statistical tools. The findings suggest that the pandemic could not change consumer attitude significantly, but the order of factors influencing purchases changed. Consumer motivation factors were organized into four well-distinguished factors: Healthy, domestic, and environmentally friendly choice; Usual taste and quality; Reasonable price; Shelf life. Due to the lack of outstanding data during segmentation, we developed four segments by hierarchical cluster analysis: Health- and environment-conscious women; Price sensitive young people; Taste-oriented men; Quality-oriented intellectuals. The results confirm that food manufacturers and traders need to be prepared for further restrictions in the future.
\end{abstract}

Keywords: food purchase behavior; COVID-19; Hungary; pandemic

\section{Introduction}

Over the past two and a half decades, the number of research related to food purchase has multiplied. One of the important conclusions of these behavioral surveys is that consumers strive to choose the right quality of food during purchase. However, food cannot have the main function of alleviating hunger as a sole function but must also provide people with the nutrients they need to prevent the development of nutrition-related diseases. In addition, food should guarantee the physical improvement and mental wellbeing of consumers [1,2]. According to Grunert and Wills (2007), persuading consumers to eat healthier is not an obvious responsibility. Their research highlighted that each person appreciates health, therefore they need to be informed about the link between diet and a healthy lifestyle [3]. Research shows that health awareness motivates consumers highly when opting for food, but the quality and taste of food are also key factors [4-11].

Consumers increasingly believe that food they consume contributes to their health directly [12-15].

\subsection{Theoretical Background of Food Choice}

One of the main research focuses on food choice decisions is the study of consumer behavior types related to obesity [16-19] in which the research models examine food 
consumers' choices. Researchers refer to two basic quantitative models when examining this decision-making process [20-24].

One is the Food Choice Questionnaire (FCQ) in which Steptoe et al. (1995) examined food choice habits through 36 statements [25]. The authors identified nine factors that cover the motivations of those involved in the questionnaire in their food choices. These include health; mood; comfort; a sensory appeal; natural content; price; weight control; awareness and ethical considerations. Milošević et al. (2012) identified eight factors by factor analysis; compared to the original model, health and natural content emerged as one factor [26]. Januszewska et al. (2011) tested the questionnaire in the populations of four countries (Belgium, Hungary, Romania, Filipinos) [27].

Szakály et al. (2018) concluded, based on research conducted on a Hungarian sample, that for Hungarian consumers, sensory properties, price, and convenience factors (convenience of shopping and preparation) are the most important factors when choosing foods [28]. It is an interesting result that brand awareness, i.e., the routine, has a much greater influencing effect on the choices of Hungarian consumers than in other cultures. It is backed by the survey of Markovina et al. (2015) of nine European countries, which reveals that awareness is one of the least important factors in other European cultures [29]. At the same time, health aspects are less considered by Hungarian consumers compared, for example, to Serbian [30], Finnish [31], Belgian, Romanian, and Filipino [27] consumers. Of course, there are gender differences, as the health status of food is relatively more important for women, while awareness has a greater impact on men, as confirmed by the international research mentioned above. Renner et al. (2012) stated in their research those important motivational elements were not covered by the original FCQ study [32]. Using 78 statements in their TEMS model (The Eating Motivation Survey), they developed 15 factors (1. pleasure, 2. habits, 3. need and hunger, 4 . health, 5. comfort, 6 . indulgence, 7. traditional eating, 8 . natural content, 9 . social life, 10 . price, 11 . visual temptation, 12. weight control, 13. emotion regulation, 14 . social norms, 15. social image), which cover, among other things, social and psychological aspects. Renner et al. (2012) based on their research on a German sample showed that participants identified motivation factors as the Liking, the Habits, the Need and the Hunger, and Health as the most common factors influencing their eating behavior [32]. In contrast, less important factors influencing choice are Social Image, Social Norms, and Affect Regulation. The results are consistent with the findings by Steptoe et al. (1995) based on FCQ [25].

Among the various models, Three Factor Eating Questionnaire (TFEQ) model as the most commonly used research tool has been developed to evaluate eating behaviors of different populations [33-35]. Originally, the survey with 51 statements was a selfassessment questionnaire whose main purpose was to analyze eating and related decisionmaking and behavioral processes among overweight individuals. TFEQ has been adapted by several researchers from several countries [36-38]. There are also shorter versions of the questionnaire that consist of fewer statements. The most common of these are the 21-item (TFEQ-R21) and 18-item (TFEQ-R18) versions, which are the most popular in psychology and sociology [39]. Karlsson et al. (2000) developed an 18-factor version of the original three-factor dietary questionnaire (TFEQ) (TFEQ-R18) [40]. TFEQ-R18, similar to TFEQ and TFEQ-R21 versions, is based on three factors: cognitive restraint (CR), emotional eating (EE), and uncontrolled eating (UE). The shortened Three-Factor Eating Questionnaire (TFEQR18) is one of the most widely used tools for evaluating eating behavior. Most TFEQ-R18 studies aim to examine overweight and obese individuals [41-44], while FLVS Study Group researchers were given the same factor structure when examining individuals with normal body weight as in the previous research by Hyland et al. (1989) [45], thus finding that the 18-statement model is also valid when examining non-obese individuals. Among their results, differences between gender and youth and adults were highlighted [46]. 


\subsection{Food Purchase Habits during the Pandemic}

On 11 March 2020, the WHO confirmed coronavirus disease (SARSCoV-2), which appeared in 2019, to be a pandemic [47]. The emergence and rapid spread of the COVID-19 pandemic poses a significant challenge to health systems around the world [48]. In its global recommendation (2020), the WHO proposed that national governments impose restrictions to curb the spread of the infection. Despite the measures, the number of confirmed cases was already above 3.5 million on 5 May 2020, and the number of confirmed deaths exceeded 250,000 [49]. Stay-at-home orders have affected not only social relationships but also the functioning of businesses and corporations, as well as the physical activity and eatingbuying habits of the population, as people worldwide could only leave their homes in extremely severe or urgent cases [50].

A pandemic can fundamentally change food purchase habits. In EY-Future-ConsumerIndex (2020) study, it is claimed that four major trends in consumer behavior emerged during COVID-19 [51]. These are as follows: 1. (CUT DEEP) 'Spend less.': This segment is made up particularly of people over the age of 45 whose employment situation has been most affected by the pandemic. 2. (STAY CALM, CARRY ON) 'Stay calm and don't change.': These consumers were not affected by the effects of the pandemic; therefore, they did not change their shopping habits. 3. (SAVE AND STOCKPILE) 'Save and store.': Consumers in this group are significantly concerned about the health of their families and the long-term development of their financial situation. 4. (HIBERNATE AND SPEND) 'Hibernate and Spend More!': The group consists mainly of 18-44-year-old people who have a duality in terms of consumer habits. On the one hand, they are concerned about the pandemic, but only $40 \%$ said they purchase less often due to this fact. However, their shopping habits have changed significantly, with $46 \%$ stating that brands are more important during shopping than before. The study examined the consumer habits of 4859 individuals in the United States, Canada, the United Kingdom, France, and Germany. Overall, 42\% of the respondents believed that the way they purchased had fundamentally changed as a result of COVID-19. The results of Güney and Sangün (2021) suggested that the changes were mainly related to fear of price increases, stockpiling, the purchase of usual and excessive quantities of food, food availability and a sense of security, as well as conscious food waste and natural foods and products related to packaging [52].

As a result of the closures, several studies found that individuals' food choice and consumption habits have changed. According to the findings of Marinković and Lazarević (2021), the fear of the negative effects of the virus and the precautions set up for prevention influenced food purchase habits of consumers significantly [53]. Marty et al. (2021) studied how changes in food choice motivations are related to changes in food quality during restrictions compared to the pre-pandemic period [54]. Nine food motivations were examined: 1 . health, 2 . comfort, 3 . sensory attractiveness, 4 . natural content, 5 . ethical concern, 6. weight control, 7. mood, 8. awareness, 9. price. Shen et al. (2020) examined the same nine motivations whether emotional eating is affected by high (73.6\%) stress levels among respondents as a result of COVID-19 [55]. The Dutch Eating Behavior Questionnaire (DBEQ) [56] and the Food Choice Questionnaire (FCQ) were applied in the evaluation. Rodríguez-Pérez et al. (2020) examined changes in the eating habits among the Spanish adult population during the closures [22]. In general, out of the motivations, mood, health, comfort, and natural content were the common motivational factors. The growing popularity of digital trade has been examined in a study published by McKinsey \& Company that analyzed consumer behavior in 45 countries [57]. According to the publication, online customer base growth is on average $30 \%$. Due to increased uncertainty, consumers spend most of their expenditure on basic products and reduce discretionary spending (on non-basic products and services).

Szonda Ipsos Media, Opinion and Market Research Institute (https: / /www.ipsos.com/ hu-hu/elerheto-valsag-hatasait-fogyasztoi-szempontbol-vizsgalo-kutatassorozat-elso-hetiriportja, accessed on 8 June 2021) has been measuring the effects of coronavirus epidemic on consumer behavior in Hungary from April 2020 on a weekly basis, i.e., from the first days 
of the stay-at-home order. The situation emerged as a result of the coronavirus reshapes the lifestyle, habits, behavior, and decision-making mechanisms of consumers fundamentally. As a result of the pandemic, half of the adult domestic population (52\%) do not leave their homes at all, while only one in twelve still leaves their homes as usual ( $8 \%$ ). In March-April 2020, Soós conducted an online questionnaire survey on changes in domestic consumer behavior as a result of COVID-19 [58]. In his study, she explains that consumers choose smaller stores and markets instead of larger malls, and the role of online shopping has increased. The extent of the decrease in personal purchases is well-shown by the database of the Hungarian Central Statistical Office. Based on data of the Hungarian Central Statistical Office (2021), we can see that while in March 2019 the turnover of domestic retail stores increased by $4.9 \%$, in April by $8.5 \%$ and in May by $5.0 \%$ compared to the same period of 2018 , by 2020 after an increase of 3.5\% in March, the turnover of retail stores decreased by $10.2 \%$ in April and by $2.1 \%$ in May compared to 2019 [59].

The COVID epidemic has created a new situation for both food supply companies and consumers on the demand side, patterns of which have not been available so far. Thus, as a research problem, we attempted to assess what patterns of food purchasing behavior can be observed among consumers in the event of a hitherto unknown emergency. That is, how an external constraint changes food-purchasing behavior.

A review of the literature has revealed that so far, few studies have examined the changes in consumers' motivations for buying food in the context of the COVID epidemic. Consequently, our most crucial goal is to examine the motivations of the Hungarian population for food purchases during the restrictions caused by the first wave of COVID-19. In our study, we analyze whether the motivations of the Hungarian population to buy food have changed as a result of the emergency generated by the pandemic. For comparability, we assessed the pre-pandemic situation, which we compared with the situation in the first wave. Ideally, our findings would provide guidance to food producers on how to change their products, sales channels, and communications in response to the expected additional needs, in line with the changing needs of consumers.

\section{Materials and Methods}

\subsection{Sampling}

Experts from the National Food Chain Safety Office, the Institute of Marketing and Trade of the Faculty of Economics of the University of Debrecen, and the TÉT Platform conducted a survey examining the impact of the epidemiological situation on food consumption in the form of an online questionnaire during COVID-19.

The survey took place from 2 to 19 May 2020. A link generated from a questionnaire editing interface was shared on the most popular social network in Hungary in the form of a post. Paid ad campaigns were associated with that post. These campaigns were advertised to all target groups with the same image and wording. In order to create a representative sample in terms of gender and age, five parallel advertisements by age groups were placed in the first wave. The duration of the first wave of ads was four days, from Friday morning to the following Tuesday morning. Based on the data of the incoming questionnaires, the socio-demographic distribution of the respondents was continuously monitored. Then, in the next wave of advertising, the demographic groups, up to that point representing a smaller proportion of respondents were targeted. This second wave was a more concentrated campaign in terms of time, with a maximum of two days. The purified sample consists of 3000 items. The sample was weighted so that the sample could represent the Hungarian adult population aged 18 and older by gender and age. As the number of the examined age group in Hungary is approximately 8000 thousand [59] and with a 95\% confidence level and a 5\% margin of error, based on the work of Gill and Johnson (2002), the required sample size is 385 , the sample size is appropriate for the study objectives [60]. 


\subsection{Structure of the Questionnaire}

The quarantine questionnaire consisted of three major blocks: 1 . food purchase, 2. nutrition, food consumption and physical activity, 3. food supply and safety. The block examining food purchasing habits was further divided into three sub-blocks: 1.1. purchase motivations, 1.2. frequency of shop visits, 1.3. purchase volume of certain food categories.

The present article discusses only the results concerning food purchasing motivations. The set of questions on motivations was based on a model used by the authors in a previous study examining food choice motivations. [61]. This part of the questionnaire consisted of three parts. In the first part, respondents had to answer how important various factors influencing purchasing were in the pre-epidemic period. The second part of questions analyzed the same factors influencing purchasing, only in the first wave of the pandemic. Factors influencing the purchase used are illustrated in Table 1.

Table 1. Factors influencing purchase and their measurement $(\mathrm{N}=3000)$.

\begin{tabular}{cc}
\hline Factors Influencing Purchase & Measuring Scale \\
Constantly high quality & \\
Flavors associated with the product \\
Popular and usual brand \\
Convincing advertisement \\
Favorable price \\
Integration into healthy diet \\
Discount price \\
The food was produced in Hungary \\
Bio/ecological origin \\
Environmentally-friendly packaging \\
The product is packaged \\
Shelf life of the food \\
important $1-$ not \\
Local product/food from small farms \\
It has trademark
\end{tabular}
Source: [61].

In the last part of the block, we questioned about the socio-demographic characteristics of the respondents (gender, age, type of settlement, region, highest level of education completed, subjective sense of income, perceived health, and environmental awareness). Table 2. shows the percentage distribution of the socio-demographic groups of the individuals involved in the survey and the population composition according to the previously mentioned two factors.

\subsection{Data Analysis}

Data analysis was performed with SPSS mathematical-statistical analysis software. In order to achieve the research goals, we used both descriptive and multivariate statistical tools. Among the descriptive methods, mean, standard deviation, coefficient of variation, and skewness were calculated. We carried out exploratory factor analysis at first out of the multivariate statistical methods. The purpose of Empirical Distribution Function Statistics (EDF) was to explore what factors can influence purchasing factors during a pandemic. Afterwards, we examined the reliability of the scales used within the measurement model of the revealed latent variables, using Cronbach's alpha and composite reliability indicators. Segmentation was performed by cluster analysis, which consisted of two main steps: in the first step we determined the number of clusters/segments by hierarchical cluster analysis, then we performed the cluster analysis using K-means method in such a way that the cluster mean was left to the applied program. Cross-tabulation analysis and simple hypothesis tests were used to examine the clusters. 
Table 2. Distribution of the sample according to the most important background variables $(\mathrm{N}=3000)$ and population composition according to representative variables.

\begin{tabular}{|c|c|c|c|}
\hline \multirow{2}{*}{$\begin{array}{c}\text { Background Variables } \\
\text { Female }\end{array}$} & \multicolumn{2}{|c|}{ Sample Distribution } & \multirow{2}{*}{$\begin{array}{c}\begin{array}{c}\text { Population } \\
\text { Distribution }\end{array} \\
52.2\end{array}$} \\
\hline & 1587 & 52.9 & \\
\hline Male & 1413 & 47.1 & 47.8 \\
\hline $18-29$ & 507 & 16.9 & 17.2 \\
\hline $30-39$ & 483 & 16.1 & 16.0 \\
\hline $40-59$ & 1044 & 34.8 & 34.7 \\
\hline $60-$ & 966 & 32.2 & 32.1 \\
\hline Budapest & 1059 & 35.3 & \\
\hline Other towns & 1530 & 51.0 & \\
\hline Village & 411 & 13.7 & \\
\hline Central Hungary & 1515 & 50.5 & \\
\hline Southern Great Plain & 282 & 9.4 & \\
\hline Northern Great Plain & 267 & 8.9 & \\
\hline Northern Hungary & 261 & 8.7 & \\
\hline Central Transdanubia & 252 & 8.4 & \\
\hline Western Transdanubia & 243 & 8.1 & \\
\hline Southern Transdanubia & 180 & 6.0 & \\
\hline Primary school & 36 & 1.2 & \\
\hline Vocational school & 219 & 7.3 & \\
\hline High school & 984 & 32.8 & \\
\hline Higher education & 1761 & 58.7 & \\
\hline Can live on it but can save little & 1215 & 40.5 & \\
\hline Can live on it very well and can also save & 993 & 33.1 & \\
\hline Just enough to live on but cannot save & 624 & 20.8 & \\
\hline Sometimes cannot make ends meet & 78 & 2.6 & \\
\hline Have regular financial problems & 27 & 0.9 & \\
\hline Not known/No answer & 63 & 2.1 & \\
\hline Mostly health conscious & 1564 & 52.1 & \\
\hline $\begin{array}{l}\text { Health-conscious and not } \\
\text { health-conscious }\end{array}$ & 834 & 27.8 & \\
\hline Very health conscious & 296 & 9.9 & \\
\hline Mostly not health conscious & 209 & 7.0 & \\
\hline Not health conscious at all & 67 & 2.2 & \\
\hline Not known/No answer & 30 & 1.0 & \\
\hline Mostly environmentally conscious & 1723 & 57.4 & \\
\hline Both environmentally conscious and not & 621 & 20.7 & \\
\hline Very environmentally conscious & 469 & 15.6 & \\
\hline Mostly not environmentally conscious & 141 & 4.7 & \\
\hline Not environmentally conscious at all & 26 & 0.9 & \\
\hline Not known/No answer & 20 & 0.7 & \\
\hline
\end{tabular}

Note: ${ }^{1}$ Source of data $[62,63]$.

\section{Results}

\subsection{Examining Customer Behavior before and during the First Wave}

We first asked how important the aspects listed below were for respondents when purchasing food before coronavirus. The results are shown in Table 3.

The results showed that two factors reached value above 4 , these included taste and consistent quality. In this case, the standard deviation and coefficient of variation are particularly low, and the skewness, especially in case of taste, is strongly negative. This means that respondents consider these aspects to be more important. This is followed by the popular and usual brand, favorable price, integration into a healthy diet and the shelf life of the food. The search for Hungarian products and local products/food from small 
farm is a relatively important aspect, but environmentally friendly packaging is also of medium importance. Bio/organic origin and advertising are still at the bottom of the list.

Table 3. Importance of purchasing factors when buying food before coronavirus $(\mathrm{N}=3000)$.

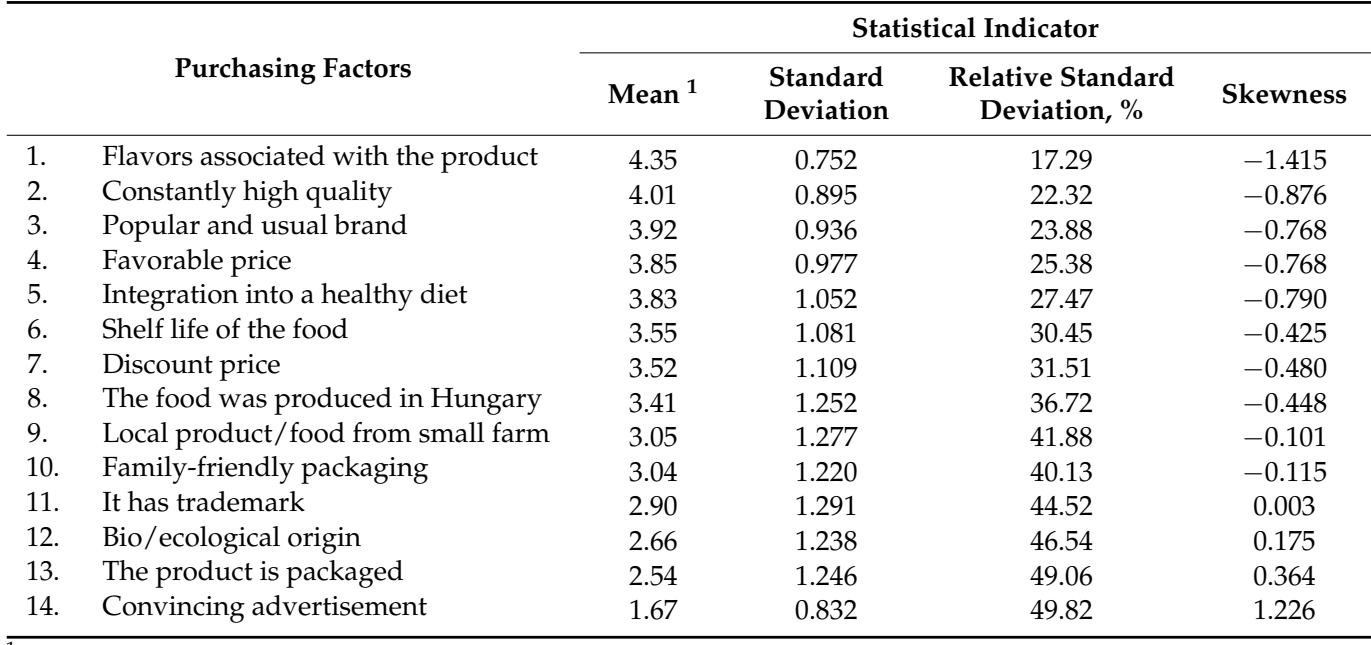

${ }^{1}$ Results were rated on a scale of 1 to 5 , with a value of 1 for 'Not important at all' and a value of 5 for 'very important'.

In the following, we examined how the direction of consumers' thinking about food purchases changed during coronavirus. Related data are shown in Table 4.

Table 4. Importance of purchasing factors when buying food during coronavirus $(\mathrm{N}=3000)$.

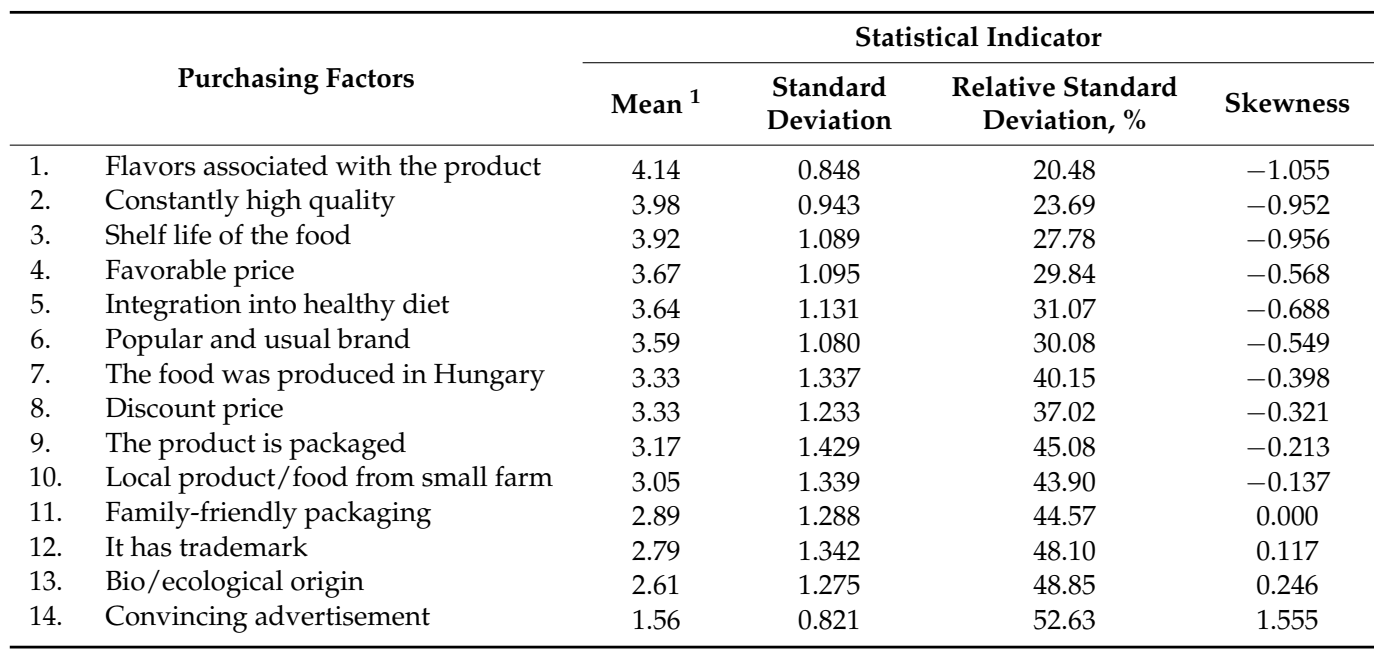

${ }^{1}$ Results were rated on a scale of 1 to 5 , with a value of 1 for 'Not important at all' and a value of 5 for 'very important'.

It can be clearly seen that the first two ranks did not change compared to the prepandemic situation. Taste and consistent quality are basic expectations of consumers, and a crisis or epidemic cannot change that. Shelf life of the food, on the other hand, has advanced three places, the mean increased, the standard deviation and coefficient of variation decreased, and consumers agree with this influencing factor to a greater extent than in the pre-pandemic period. At the same time, the popular and usual brand declined, indicating that the brand and its usual aspect are not so important to consumers during a crisis, it is easier for consumers to give them up, often out of compulsion. Similarly, the packaged product moved up the hierarchy, which typically moves with shelf life. The Hungarian origin of the product maintained its position during the pandemic, but it could not improve on the importance mean. Environmentally friendly packaging, trademark, organic origin, and advertisement all ranked in the last places. 


\subsection{Factor Analysis}

Based on the exploratory factor analysis, we were able to identify four factors (Table 5). During the analysis, we obtained a model with a high explanatory power of $65.093 \%$. The first, strongest factor was named 'Healthy, Domestic, and Environmentally Friendly Choices,' which explains $27.242 \%$ of the variance. High factor weights suggest that the value dimension shapes shopping habits of Hungarian consumers to a large extent and sharply separated from the others. Regarding the Skewness indicator, it can be concluded that the distribution is significantly skewed to the left (Skewness $=-0.187$ ), i.e., Hungarian consumers consider this way of thinking to be more relevant for themselves. The second factor is 'Usual taste and quality', which explains $9.919 \%$ of the variance, related to the taste of the products and their constant quality. The factor is skewed to the left (Skewness $=-0.864)$, i.e., Hungarian consumers are more typical of these statements. The third factor is 'Favorable Price', which includes claims about product price developments. The factor explains $9.749 \%$ of the variance, and the high factor weights suggest that the dimension shapes the thinking of Hungarian consumers to a large extent. The left skewness of the factor is also expressed (Skewness $=-0.439$ ). The fourth and weakest factor is 'Shelf life' which explains $7.724 \%$ of the variance. With respect to the skewness of the factor, it can be concluded that the distribution is skewed to the left (Skewness $=-0.200$ ), i.e., this way of thinking is also considered more relevant for themselves in the study. Convincing advertisement as a factor influencing purchasing was based on several factors and appeared with a low factor weight, therefore we deleted it from the factors.

Table 5. Results of exploratory factor analysis $(\mathrm{N}=3000)$.

\begin{tabular}{|c|c|c|c|c|}
\hline Factors Influencing Purchase & $\begin{array}{l}\text { Healthy, Domestic, } \\
\text { and Environmentally- } \\
\text { Friendly } \\
\text { Choice }\end{array}$ & $\begin{array}{c}\text { Usual Taste and } \\
\text { Quality }\end{array}$ & $\begin{array}{l}\text { Favorable } \\
\text { Price }\end{array}$ & $\begin{array}{l}\text { Shelf } \\
\text { Life }\end{array}$ \\
\hline Local product/food from small farm & 0.817 & & & \\
\hline The food was produced in Hungary. & 0.796 & & & \\
\hline Bio/ecological origin & 0.736 & & & \\
\hline Environmentally packaging & 0.704 & & & \\
\hline It has trademark & 0.685 & & & \\
\hline Integration into a healthy diet & 0.508 & & & \\
\hline Convincing advertisement & & & & \\
\hline Flavors associated with the product & & 0.788 & & \\
\hline Constantly high quality & & 0.704 & & \\
\hline Popular, usual brand & & 0.523 & & \\
\hline Favorable price & & & 0.897 & \\
\hline Discount price & & & 0.791 & \\
\hline The product is packaged & & & & 0.925 \\
\hline Shelf life of the food & & & & 0.437 \\
\hline
\end{tabular}

Extraction method: Maximum Likelihood; Rotation method: Varimax rotation; Rotation converged in 5 iterations; $\mathrm{KMO}=0.820$ (incredibly good); Bartlett: (Approx. Chi Sq.) 14,477.24; (Sig.) 0.000; Communalities: 0.118-0.884 Cumulative explained variance: $65.093 ; \mathrm{N}=3000$.

\subsection{Examination of the Suitability of the Measurement Tool}

Before segmentation, we had to test the suitability of the measurement tool for further surveys. Reliability was examined with the Cronbach's alpha index and the composite reliability (CR) index, based on which our measurement tool can be considered reliable, and reliability cannot be further increased by removing items $[64,65]$. The results of the reliability test are summarized in Table 6.

\subsection{Segmentation}

During segmentation, the segmentation criteria were the previously defined attitudes (factors): Healthy, domestic, and environmentally friendly choice, Usual taste and quality, Favorable price, Shelf life. Once our data proved suitable for segmentation, we determined the number of clusters by hierarchical cluster analysis and examined whether we had outliers. Since no outliers were found and the number of segments was determined in 
4 clusters, we ran the cluster analysis using K-means method, during which the determination of the cluster means was left to the algorithm. The formed clusters differ significantly from each other $(p<0.01)$ based on the analysis of variance, i.e., the result of the segmentation is valid. We were able to involve a total of 2748 people in the clusters. In the following, a detailed characterization of each cluster is performed in accordance with the objectives of the research.

Table 6. Reliability of the measuring instrument.

\begin{tabular}{ccc}
\hline Factors & Cronbach's Alpha Index & Composite Reliability \\
\hline Healthy, domestic, and & 0.878 & 0.891 \\
environmentally-friendly choice & 0.716 & 0.608 \\
Usual taste and quality & 0.829 & 0.444 \\
Favorable price & 0.595 & 0.210 \\
Shelf life &
\end{tabular}

Source: based on own calculation.

\section{- Cluster 1-Health and environment-conscious women}

The proportion of the group is $30.8 \%$ (847 people) among all respondents. Within the segment, women are significantly over-represented $(37.4 \%)$ and dominated by the oldest (over 60-40.5\%). Within the group, the number of 18-29-year-old and 30-39-year-old people (23.9\% and $21.6 \%$, respectively) is low. The group has a higher proportion of those with vocational education/technical education (35.7\%) and high school graduates (34.5\%). More than $60 \%$ of the cluster is made up of people living in better financial conditions, who, in addition to their daily livelihood, can save to a greater or lesser extent. Those whose income decreased significantly as a result of the pandemic (36.1\%) are in the majority, while those who 'increased compared to the past' (16.2\%) represent a smaller number in the cluster. They typically live in cities $(34.1 \%)$ and villages $(32.5 \%)$. The members of the cluster are characterized by health and environmental awareness; 'Very health conscious' (35.4\%) and 'Very environmentally conscious' (33.5\%) dominate.

This cluster is characterized by multilevel awareness, as they rated most of the motivational factors as the highest. It is also their characteristic that they monitor the shelf life, packaging, and price of the food. In addition, they typically prefer products that are already popular or usual, but also consider flavors associated with a particular product and the consistently high quality. They also make sure that these products can be easily integrated into a healthy diet. The cluster significantly overestimates the Hungarian origin and the local products/food from small farms compared to other segments. This is backed by the predominance of health- and environment-conscious individuals in the cluster.

\section{- Cluster 2-Price sensitive young people}

The proportion of the group is $16.0 \%$, i.e., 439 people, making it the smallest cluster. The proportion of women $(15.8 \%)$ and men $(16.1 \%)$ in the segment is almost the same. The cluster is dominated by those aged 18-29 (22.0\%). In the group, people over the age of $60(11.9 \%)$ and those aged $40-59(15.3 \%)$ are present in low numbers. The segment is dominated by those with a 'grade 8 education' $(33.3 \%)$, while the number of people with a tertiary education is low (13.0\%). Examining their income situation, they are characterized by rather a worse financial situation. As a result of the pandemic, those who lost their previous income $(39.5 \%)$ are represented in the group in an outstanding proportion. Typically, urban residents make up the cluster $(49.66 \%)$. The group is not typically health and environmental conscious. 'Not health-conscious at all' $(38.7 \%)$ and 'Not environmentally conscious at all' (42.1\%) dominate.

For those in the cluster, the price of the products is extremely important, and advertising related to the product is not important at all. The shelf life and packaging of food is also important. They can be considered less health and environmental conscious and the high-quality food is less important, as well as the bio/ecological origin, and this group is the least motivated by the Hungarian origin and the purchase from local producers. 


\section{- $\quad$ Cluster 3-Taste-oriented men}

Based on its size, it is the second largest cluster $(27.1 \%, 744$ people) of the four. Gender is strongly dominated by men (32.8\%) while the rate of women is lower $(21.9 \%)$. Among the age groups, those aged 18-29 (34.9\%) and 30-39 (33.8\%) stands out slightly. People over the age of 60 are present in lower numbers in the group (20.4\%). The segment is dominated by a maximum of ' 8 grade education' (36.4\%). Other education groups make up the cluster in almost equal proportions. Within the group, those in the average financial situation (they can make ends meet but can save little-31.2\%) and (Just enough to make ends meet, but unable to save-26.6\%) play a decisive role. Within the segment, the majority are those whose income increased during the pandemic (35.1\%). According to the place of residence, the population of the capital $(28.8 \%)$, the inhabitants of the village $(27.2 \%)$ and the city $(25.9 \%)$ occur in almost the same proportion within the group. In the group, 'Mostly not health-conscious' (36.1\%) and 'Mostly not environmentally conscious' (45.0\%) people stand out in the group.

For those in the cluster, convincing advertisements are not important at all, but the taste and enjoyment value associated with the products is important. It is not important, either, that the product they buy is packaged, and it is less characteristic to pay attention to the environmentally friendly characteristics of the product they buy. The health factor of the product as well as its organic/ecological origin are not considered when making a purchase decision.

\section{- Cluster 4-Quality-oriented intellectuals}

According to the subjective sense of income, those with slightly better income than average (they make a living from it, but they can save little-36.3\%), and those with much better income than average (they make a good living from it and can save- $32.7 \%$ ) dominate in the group. The group was over-represented by those whose income increased during the pandemic compared to the previous period (35.1\%). Within the group, the residents of the capital $(28.5 \%)$, those living in the village $(26.1 \%)$ and the city $(24.5 \%)$ are almost equally represented. 'Mostly not health-conscious' (27.9\%) and 'Very health-conscious' (26.1\%) appear in the cluster in almost the same proportion. This duality can also be observed when examining subjective environmental awareness.

Convincing advertisement related to the product, or favorable or discount price are less important, which may be related to better financial situation. Typically, it is the flavor associated with the product and consistent quality that influence them when shopping. To a lesser extent, but the packaged and durable nature of the product they want to buy is also important; however, environmentally friendly packaging is moderately important. Slight brand loyalty characterizes the segment, while integration into a healthy diet is somewhat more important than moderate.

\section{Discussion}

In our study, we undertook to present the influencing effect of the restrictions experienced during the first wave of COVID-19 on food choice and food purchase habits of Hungarian consumers. We found that the pandemic could not change consumer thinking; however, the order of some factors changed. Compared to the period before closure, the shelf life and packaged nature of the products are those that came first in order of priority. This result is consistent with the results of Güney and Sangün (2021) [52], where the authors found that the mode of product packaging influenced food motivation significantly during the pandemic. According to research by European Institute of Innovation \& Technology (EIT-Food, 2020), since the outbreak of COVID-19, 33\% of consumers have paid more attention to the packaging of the product they intend to choose [66]. However, while in our study packaging was an important factor mainly during the pandemic due to the shelf life of food, in the EIT-Food (2020) research, the need for environmentally conscious packaging also appeared to a minimal extent [66]. In our research, the issue of environmental awareness was somewhat pushed into the background during the pandemic period. The 
weight of environmental sustainability in food packaging also appears to be declining compared to the pre-pandemic period, according to an International Food Information Council (IFIC, 2021) study, but their research shows that more than half of consumers still consider environmentally friendly packaging important [67]. Of course, packaging is also related to the shelf life of the products. Fear of this can also be observed in the IFIC (2021) Food and Health Survey, with $40 \%$ of consumers being worried about the early expiry of the shelf life of the food they buy [67].

Examining customer behavior in the pre-pandemic period, as well as during the first wave of the epidemic, 'product-related flavors' aspect was the most important to consumers. This result is consistent with a previous study by Glanz et al. (1998) [18], where the authors suggest that people are more likely to choose foods during purchase, they find delicious. This kind of perception can also be observed in the IFIC (2021) study, as $82 \%$ of those surveyed identified taste as the strongest motivation to buy [67]. Although the value of motivation for product taste decreased compared to the previous year, it is still the factor that most influential regarding consumers' final decision. This was followed by the price of the products $(66 \%)$, their health property $(58 \%)$, the convenience of shopping $(52 \%)$ and the environmental sustainability of the products $(31 \%)$. In our study, the role of brand loyalty decreased during the pandemic, which is consistent with the study by Arora et al. (2020) [57]. According to their results, when consumers could not find their preferred product s) in their usual and popular store due to the pandemic, they changed their purchasing behavior and other brand(s) or store(s).

According to EIT-Food (2020) research, the persistently favorable prices and availability of products appear to be re-evaluating, and in the post-pandemic period, factors related to the convenience of food purchases and food prices come to the fore [66]. According to our study, the motivational power of the special price and the persistently low price of products decreased overall, but the influencing role of food prices in certain social strata strengthened. This group includes particularly young people who lose their jobs and incomes.

Hungarian origin maintained its position during the pandemic. According to Hobbs (2020), it seems likely that demand for local foods after COVID-19 will increase in the short to medium term, as the importance of local foods is a well-established consumer trend that, according to Cranfield et al. (2012), has economic, social, environmental, and health benefits $[68,69]$.

Table 7 summarizes the results of research examining the food choice motivations of Hungarian consumers based on different models.

Table 7. Hungarian consumers' food choice motivations based on different models in the precoronavirus period and during the first wave.

\begin{tabular}{cll}
\hline Model (Year of Questioning) & \multicolumn{2}{c}{ Factors in Order of Importance } \\
\hline & 1. & Sensory Appeal, \\
FCQ, 2018 & 2. & Price and Purchase Convenience, \\
(Food Choice Questionnaire) & 3. & Preparation Convenience, \\
{$[28]$} & 5. & Familiarity, \\
& 6. & Moalth and Natural Content (+Weight Control), \\
& 7. & Ethical concerns. \\
\hline TFEQ, 2019 & 1. & Emotional Eating, \\
(Three Factor Eating Questionnaire) & 2. & Uncontrolled Eating, \\
{$[24]$} & 3. & Cognitive Restraint Factor \\
\hline
\end{tabular}


Table 7. Cont.

\begin{tabular}{|c|c|}
\hline Model (Year of Questioning) & Factors in Order of Importance \\
\hline $\begin{array}{c}\text { TEMS, } 2019 \\
\text { (Eating Motivation Survey) } \\
{[70]}\end{array}$ & $\begin{array}{ll}\text { 1. } & \text { Pleasure, } \\
\text { 2. } & \text { Habits, } \\
\text { 3. Need and Hunger, } \\
\text { 4. Health, } \\
\text { 5. Comfort, } \\
\text { 6. Traditional Eating, } \\
\text { 7. Indulgence, } \\
\text { 8. Natural Content, } \\
\text { 9. Price, } \\
\text { 10. Social Life, } \\
\text { 11. Weight Control, } \\
\text { 12. Visual Temptation, } \\
\text { 13. Social Image, } \\
\text { 14. Social Norms, } \\
\text { 15. Emotion Regulation. }\end{array}$ \\
\hline Before COVID-19 (2020) & $\begin{array}{l}\text { 1. Flavors associated with the product, } \\
\text { 2. Constantly high quality, } \\
\text { 3. Popular and usual brand, } \\
\text { 4. Favorable price, } \\
\text { 5. Integration into a healthy diet, } \\
\text { 6. Shelf life of the food, } \\
\text { 7. Discount price, } \\
\text { 8. The food was produced in Hungary } \\
\text { 9. Local product/food from small farm, } \\
\text { 10. Family-friendly packaging, } \\
\text { 11. It has trademark } \\
\text { 12. Bio/ecological origin, } \\
\text { 13. The product is packaged, } \\
\text { 14. Convincing advertisement }\end{array}$ \\
\hline During the first wave of COVID-19 (2020) & $\begin{array}{l}\text { 1. Flavors associated with the product, } \\
\text { 2. Constantly high quality, } \\
\text { 3. Shelf life of the food, } \\
\text { 4. Favorable price, } \\
\text { 5. Integration into healthy diet, } \\
\text { 6. Popular and usual brand, } \\
\text { 7. The food was produced in Hungary, } \\
\text { 8. Discount price, } \\
\text { 9. The product is packaged, } \\
\text { 10. Local product/food from small farm, } \\
\text { 11. Family-friendly packaging, } \\
\text { 12. It has trademark, } \\
\text { 13. Bio/ecological origin, } \\
\text { 14. Convincing advertisement }\end{array}$ \\
\hline
\end{tabular}

According to Szakály (2008), 86\% of Hungarian consumers rarely or never give up on the good taste of food for the sake of its healthiness. Based on the author's research, it can be stated that European consumers prefer the enjoyment value over the healthiness of the products (taste orientation), as opposed to Asian consumers, who have a preference for nutritional benefits [71]. As can be seen from Table 7, even such an extraordinary epidemic situation could not affect the priority of taste in the Hungarian market. However, it should be noted that in recent years, a favorable attitude towards healthy eating has become more and more pronounced in Hungary, as shown by the motivational rankings of the various models. While at the time of the study carried out based on the FCQ model (2018), health was among the least important aspects, based on the TEMS model (2019) and the present research, it ranks fourth to fifth among motivations. Thus, although Hungarian consumers 
did not give up on taste during the quarantine, they were trying to create a diet as healthy as possible.

The fact that storage life and the packaged nature have come to the fore can be attributed to the panic purchase typical of the first wave of the epidemic. In addition, the opportunity to make a good purchase remained a major motivation. It is worth noting that ethnocentric thinking is also gaining ground.

\section{Conclusions}

Results indicate that the motivations of Hungarian consumers to choose food did not change in the first wave of COVID-19; however, the order of preference changed. During the period considered, the excellent taste of the products and the consistently high quality associated with the selected products retained their leading position, ahead of health considerations. This order of priority also determines the directions and opportunities of product development. For Hungarian (and generally European) consumers, existing products with a familiar taste need to be enriched with functional, health-promoting features, thus nudging them towards healthier choices.

As a result of the lockdown, the importance of the popular, familiar brand has decreased, suggesting that consumers are more likely to give up their regular brand and product if they experience a crisis. The shorter distribution channels have become slightly more appreciated, which has proved to be beneficial for food produced in Hungary.

This result was also supported by factor analysis. Customer motivational factors were divided into four well-distinguished factors, which we referred to as: Healthy, domestic, and environmentally friendly choices; Usual taste and quality; Reasonable price; Shelf life, out of which it was the price factor that appeared to be more important during quarantine, suggesting that its influential role was greater in this period. Nearly $20 \%$ of the population lost their income, or else their income fell significantly during the period of restrictions, while slightly more than $20 \%$ expect their household income to decline in the future. Accordingly, it can be assumed that the influencing factors related to food prices will come to the fore in the future.

Another important outcome of our survey is that consumer segments have become basically divided into three parts; along with the demanding and ethnocentric shoppers, those favoring taste and cosmopolitans, as well as rational shoppers, were present. It is worth highlighting the demanding, quality-oriented customers, as they were the ones who lived extremely consciously during the quarantine period: they paid attention to the use of food, studied food labels more thoroughly and tried to eat even healthier than before, and they can also be characterized by a high level of patriotism. This multi-level awareness makes them fully suited to act as a kind of reference group for those who want to follow a healthy and conscious lifestyle, as well as to be a primary target group for companies. Of course, taking priorities into account, additional target groups can be identified, such as those who are enjoyment value-oriented or price-sensitive, which allows for even more specific strategies.

The positive result of our research is that the motivational factors and clusters identified enable us to predict the reactions of the population, thus helping organize the supply chain and increase the reaction speed of companies in other, similar situations.

The limitation of the study is the lack of study models. For the sake of comprehensive research, it would therefore be necessary to associate a model or models with the study, which would facilitate comparison with research results on a similar topic.

Author Contributions: Conceptualization, T.M., Z.S., E.A., G.K., D.S., E.K.; Methodology, T.M., Z.S.; Formal Analysis, T.M., Z.S., G.K., D.S.; Investigation, Z.S., E.A., E.K.; Writing-Original Draft Preparation, T.M., Z.S., E.A., G.K., D.S., E.K.; Writing-Review \& Editing, T.M., Z.S., E.K. All authors have read and agreed to the published version of the manuscript.

Funding: This research was funded by the EFOP-3.6.1-16-2016-00022 project. The project is cofinanced by the European Union and the European Social Fund. 
Institutional Review Board Statement: This study was conducted according to the guidelines laid down in the Declaration of Helsinki and all procedures involving human subjects were approved by the Research Ethics Committee at the University of Debrecen, Faculty of Economics and Business (approval number: GTKDH/76/2021).

Informed Consent Statement: Verbal informed consent was obtained from all subjects involved in the study. Verbal consent was witnessed and formally recorded.

Data Availability Statement: The data presented in this study are available on request from the corresponding author. The data are not publicly available due to ethical restrictions.

Conflicts of Interest: The authors declare no conflict of interest.

\section{References}

1. Menrad, K. Market and marketing of functional food in Europe. J. Food Eng. 2003, 56, 181-188. [CrossRef]

2. Roberfroid, M.B. Prebiotics and probiotics: Are they functional foods? Am. J. Clin. Nutr. 2000, 71, 1682S-1687S. [CrossRef] [PubMed]

3. Grunert, K.G.; Wills, J.M. A review of European research on consumer response to nutrition information on food labels. J. Public Health 2007, 15, 385-399. [CrossRef]

4. Ares, G.; Giménez, A.; Deliza, R. Influence of three non-sensory factors on consumer choice of functional yogurts over regular ones. Food Qual. Prefer. 2010, 21,361-367. [CrossRef]

5. Bech-Larsen, T.; Grunert, K.G.; Poulsen, J. The Acceptance of Functional Foods in Denmark, Finland and the United States: A Study of Consumers' Conjoint Evaluations of the Qualities of Functional Foods and Perceptions of General Health Factors and Cultural Values; University of Aarhus, Aarhus School of Business, The MAPP Centre: Aarhus, Denmark, 2001.

6. Grunert, K.G.; Bech-Larsen, T.; Bredahl, L. Three issues in consumer quality perception and acceptance of dairy products. Int. Dairy J. 2000, 10, 575-584. [CrossRef]

7. Grunert, K.G.; Dean, M.; Raats, M.; Nielsen, N.A.; Lumbers, M. A measure of satisfaction with food-related life. Appetite 2007, 49, 486-493. [CrossRef] [PubMed]

8. Lonneker, J. Psychological impacts of health claims on consumer perception and behaviour. In Proceedings of the ILSI International Symposium on Functional Foods in Europe, Portomaso, Malta, 9-11 May 2007.

9. Patterson, N. Exploring consumer attitudes. Taste versus convenience and health-What do consumers really want. In Proceedings of the 3rd Functional Food net Meeting, Liverpool, UK, 18-19 September 2006.

10. Salleh, M.M.; Ali, S.M.; Harun, E.H.; Jalil, M.A.; Shaharudin, M.R. Consumer's perception and purchase intentions towards organic food products: Exploring attitude among academician. Can. Soc. Sci. 2010, 6, 119-129.

11. Urala, N.; Lähteenmäki, L. Reasons behind consumers' functional food choices. Nutr. Food Sci. 2003, 33, 148-158. [CrossRef]

12. Lappalainen, R.; Kearney, J.; Gibney, M. A pan EU survey of consumer attitudes to food, nutrition and health: An overview. Food Qual. Prefer. 1998, 9, 467-478. [CrossRef]

13. Saher, M.; Arvola, A.; Lindeman, M.; Lähteenmäki, L. Impressions of functional food consumers. Appetite 2004, 42, 79-89. [CrossRef]

14. Verbeke, W. Functional foods: Consumer willingness to compromise on taste for health? Food Qual. Prefer. 2006, 17, 126-131. [CrossRef]

15. Young, J. Functional foods and the European consumer. Spec. Publ. R. Soc. Chem. 2000, 248, 75-81.

16. Czeglédi, E.; Urbán, R. Hungarian adaptation of Three-Factor Eating Questionnaire Revised 21-item. Magy. Pszichol. Szle. 2010, 65, 463-494. [CrossRef]

17. Davis, C.; Patte, K.; Levitan, R.; Reid, C.; Tweed, S.; Curtis, C. From motivation to behaviour: A model of reward sensitivity, overeating, and food preferences in the risk profile for obesity. Appetite 2007, 48, 12-19. [CrossRef]

18. Glanz, K.; Basil, M.; Maibach, E.; Goldberg, J.; Snyder, D. Why Americans Eat What They Do: Taste, Nutrition, Cost, Convenience, and Weight Control Concerns as Influences on Food Consumption. J. Am. Diet. Assoc. 1998, 98, 1118-1126. [CrossRef]

19. Serrem, K.; Dunay, A.; Serrem, C.; Atubukha, B.; Oláh, J.; Illés, C.B. Paucity of Nutrition Guidelines and Nutrient Quality of Meals Served to Kenyan Boarding High School Students. Sustainability 2020, 12, 3463. [CrossRef]

20. Furst, T.; Connors, M.; Bisogni, C.A.; Sobal, J.; Falk, L.W. Food Choice: A Conceptual Model of the Process. Appetite 1996, 26, 247-266. [CrossRef] [PubMed]

21. Köster, E. Diversity in the determinants of food choice: A psychological perspective. Food Qual. Prefer. 2009, 20, 70-82. [CrossRef]

22. Rodríguez-Pérez, C.; Molina-Montes, E.; Verardo, V.; Artacho, R.; García-Villanova, B.; Guerra-Hernández, E.J.; Ruíz-López, M.D. Changes in dietary behaviours during the COVID-19 outbreak confinement in the Spanish COVIDiet study. Nutrients 2020, 12, 1730. [CrossRef] [PubMed]

23. Roininen, K.; Lähteenmäki, L.; Tuorila, H. Quantification of Consumer Attitudes to Health and Hedonic Characteristics of Foods. Appetite 1999, 33, 71-88. [CrossRef]

24. Szakály, Z.; Kovács, B.; Szakály, M.; Nagy-Pető, D.T.; Gál, T.; Soós, M. Examination of the Eating Behavior of the Hungarian Population Based on the TFEQ-R21 Model. Nutrients 2020, 12, 3514. [CrossRef] [PubMed] 
25. Steptoe, A.; Pollard, T.M.; Wardle, J. Development of a Measure of the Motives Underlying the Selection of Food: The Food Choice Questionnaire. Appetite 1995, 25, 267-284. [CrossRef] [PubMed]

26. Milošević, J.; Žeželj, I.; Gorton, M.; Barjolle, D. Understanding the motives for food choice in Western Balkan Countries. Appetite 2012, 58, 205-214. [CrossRef]

27. Januszewska, R.; Pieniak, Z.; Verbeke, W. Food choice questionnaire revisited in four countries. Does it still measure the same? Appetite 2011, 57, 94-98. [CrossRef] [PubMed]

28. Szakály, Z.; Kontor, E.; Kovács, S.; Popp, J.; Pető, K.; Polereczki, Z. Adaptation of the Food Choice Questionnaire: The case of Hungary. Br. Food J. 2018, 120, 1474-1488. [CrossRef]

29. Markovina, J.; Stewart-Knox, B.; Rankin, A.; Gibney, M.; de Almeida, M.D.V.; Fischer, A.R.; Kuznesof, S.A.; Poínhos, R.; Panzone, L.; Frewer, L.J. Food4Me study: Validity and reliability of Food Choice Questionnaire in 9 European countries. Food Qual. Prefer. 2015, 45, 26-32. [CrossRef]

30. Gagić, S.; Jovičić, A.; Tešanovic, D.; Kalenjuk, B.; Snježana, G.; Ana, J.; Dragan, T.; Bojana, K. Motives for food choice among Serbian consumers. Èkon. Poljopr. 2014, 61, 41-51. [CrossRef]

31. Roos, E.; Lehto, R.; Ray, C. Parental family food choice motives and children's food intake. Food Qual. Prefer. 2012, $24,85-91$. [CrossRef]

32. Renner, B.; Sproesser, G.; Strohbach, S.; Schupp, H.T. Why we eat what we eat. The Eating Motivation Survey (TEMS). Appetite 2012, 59, 117-128. [CrossRef]

33. Stunkard, A.J.; Messick, S. The three-factor eating questionnaire to measure dietary restraint, disinhibition and hunger. J. Psychosom. Res. 1985, 29, 71-83. [CrossRef]

34. De Lauzon, B.; Romon, M.; Deschamps, V.; Lafay, L.; Borys, J.-M.; Karlsson, J.; Ducimetiere, P.; Charles, M.A. The Fleurbaix Laventie Ville Sante (FLVS) study group: The three-factor eating questionnaire-R18 is able to distin-guish among different eating patterns in a general population. J. Nutr. 2004, 134, 2372-2380.

35. Kavazidou, E.; Proios, M.; Liolios, I.; Doganis, G.; Petrou, K.; Tsatsoulis, A.; Fachantidou-Tsiligiroglou, A. Structure validity of the Three-Factor Eating Questionnaire-R18 in Greek population. J. Hum. Sport Exerc. 2012, 7, 218-226. [CrossRef]

36. Anglé, S.; Engblom, J.; Eriksson, T.; Kautiainen, S.; Saha, M.-T.; Lindfors, P.; Lehtinen, M.; Rimpelä, A. Three factor eating questionnaire-R18 as a measure of cognitive restraint, uncontrolled eating and emotional eating in a sample of young Finnish females. Int. J. Behav. Nutr. Phys. Act. 2009, 6, 41. [CrossRef]

37. De Medeiros, A.C.Q.; Yamamoto, M.E.; Pedrosa, L.F.C.; Hutz, C. The Brazilian version of the three-factor eating questionnaire-R21: Psychometric evaluation and scoring pattern. Eat. Weight Disord. Stud. Anorexia, Bulim. Obes. 2017, 22, 169-175. [CrossRef]

38. Moreira, P.; Almeida, L.; Sampaio, D.; Almeida, M.D.V. Validação de uma escala para avaliação do com-portamento alimentar de jovens universitários saudáveis. Rev. Ibero-Am. De Diagnóstico E Avaliação Psicológica 1998, 6, 125-136.

39. Keller, V.; Dernóczy-Polyák, A.; Ercsey, I. Adaptation possibilities of the three factor eating questionnaire in the field of marketing research-differences based on gender and generation. Hung. J. Nutr. Market. 2016, 3, 3-20.

40. Karlsson, J.; Persson, L.-O.; Sjöström, L.; Sullivan, M. Psychometric properties and factor structure of the Three-Factor Eating Questionnaire (TFEQ) in obese men and women. Results from the Swedish Obese Subjects (SOS) study. Int. J. Obes. 2000, 24, 1715-1725. [CrossRef] [PubMed]

41. Chong, M.F.-F.; Ayob, M.N.M.; Chong, K.J.; Tai, E.S.; Khoo, C.M.; Leow, M.K.-S.; Lee, Y.S.; Tham, K.W.; Venkataraman, K.; Meaney, M.J.; et al. Psychometric analysis of an eating behaviour questionnaire for an overweight and obese Chinese population in Singapore. Appetite 2016, 101, 119-124. [CrossRef]

42. Chui, H.; Bryant, E.; Sarabia, C.; Maskeen, S.; Stewart-Knox, B. Burnout, eating behaviour traits and dietary patterns. Br. Food J. 2019, 122, 404-413. [CrossRef]

43. Mostafavi, S.-A.; Akhondzadeh, S.; Mohammadi, M.R.; Eshraghian, M.R.; Hosseini, S.; Chamari, M.; Keshavarz, S.A. The Reliability and Validity of the Persian Version of Three-Factor Eating Questionnaire-R18 (TFEQ-R18) in Overweight and Obese Females. Iran. J. Psychiatry 2017, 12, 100-108.

44. Romon, M.; Lommez, A.; Tafflet, M.; Basdevant, A.; Oppert, J.M.; Bresson, J.L.; Ducimetière, P.; Charles, M.A.; Borys, J.M. Downward trends in the prevalence of childhood overweight in the setting of 12-year school- and community-based programmes. Public Health Nutr. 2009, 12, 1735-1742. [CrossRef]

45. Hyland, M.E.; Irvine, S.H.; Thacker, C.; Dann, P.L.; Dennis, I. Psychometric analysis of the Stunkard-Messick Eating Questionnaire (SMEQ) and Comparison with the dutch Eating Behavior Questionnaire (DEBQ). Curr. Psychol. 1989, 8, 228-233. [CrossRef]

46. Sante, F.L.V. Study Group. The Three-Factor Eating Questionnaire-R 18 is able to distinguish among different eating patterns in a general population. J. Nutr. 2004, 134, 2372-2380.

47. Tison, G.H.; Avram, R.; Kuhar, P.; Abreau, S.; Marcus, G.M.; Pletcher, M.J.; Olgin, J.E. Worldwide Effect of COVID-19 on Physical Activity: A Descriptive Study. Ann. Intern. Med. 2020, 173, 767-770. [CrossRef]

48. Mattioli, A.V.; Puviani, M.B.; Nasi, M.; Farinetti, A. COVID-19 pandemic: The effects of quarantine on cardiovascular risk. Eur. J. Clin. Nutr. 2020, 74, 852-855. [CrossRef]

49. Dong, E.; Du, H.; Gardner, L. An interactive web-based dashboard to track COVID-19 in real time. Lancet Infect. Dis. 2020, 20, 533-534. [CrossRef]

50. Atalan, A. Is the lockdown important to prevent the COVID-19 pandemic? Effects on psychology, environment and economyperspective. Ann. Med. Surg. 2020, 56, 38-42. [CrossRef] [PubMed] 
51. EY-Future-Consumer-Index. Four Consumer Behavior Trends Emerge during the COVID-19 Pandemic. 2020. Available online: https:/ / www.ey.com/en_gl/news/2020/04/four-consumer-behavior-trends-emerge-during-the-covid-19-pandemicthe-first-ey-future-consumer-index-finds (accessed on 16 May 2020).

52. Güney, O.I.; Sangün, L. How COVID-19 affects individuals' food consumption behaviour: A consumer survey on attitudes and habits in Turkey. Br. Food J. 2021, 123, 2307-2320. [CrossRef]

53. Marinković, V.; Lazarević, J. Eating habits and consumer food shopping behaviour during COVID-19 virus pandemic: Insights from Serbia. Br. Food J. 2021, 123, 3970-3987. [CrossRef]

54. Marty, L.; De Lauzon-Guillain, B.; Labesse, M.; Nicklaus, S. Food choice motives and the nutritional quality of diet during the COVID-19 lockdown in France. Appetite 2004, 157, 105005. [CrossRef]

55. Shen, W.; Long, L.M.; Shih, C.-H.; Ludy, M.-J. A Humanities-Based Explanation for the Effects of Emotional Eating and Perceived Stress on Food Choice Motives during the COVID-19 Pandemic. Nutrients 2020, 12, 2712. [CrossRef]

56. Strien, T.; Frijters, J.; Bergers, G.P.; Defares, P. The Dutch Eating Behavior Questionnaire (DEBQ) for as-sessment of restrained, emotional, and external eating behavior. Int. J. Geogr. Inf. Sci. 1986, 5, 295-315.

57. Arora, N.; Charm, T.; Grimmelt, A.; Ortega, M.; Robinson, K.; Sexauer, C.; Yamakawa, N. A Global View of How Consumer Behavior Is Changing amid COVID-19. Mcknsey and Company. 2020. Available online: https://www.mckinsey.com/ /media/ McKinsey / Business\%20Functions / Marketing\%20and\%20Sales /Our\%20Insights / A \%20global\%20view\%20 of $\% 20$ how $\% 20$ consumer\%20behavior\%20is\%20changing\%20amid\%20COVID (accessed on 5 May 2021).

58. Soós, G. Az élelmiszer-fogyasztói szokások változása a COVID-19 vírus megjelenéséhez kapcsolódóan Magyarországon. Mark. Menedzsment 2020, 54, 15-27. [CrossRef]

59. Hcso, T.S. Retail Trade by Type of Business, Monthly, Quarterly (January 2017-May 2021); Hungarian Central Statistical Office: Budapest, Hungary, 2021.

60. Gill, J.; Johnson, P. Research Methods for Managers, 3rd ed.; Sage: Thousand Oaks, CA, USA, 2002.

61. Szakály, Z.; Popovics, P.; Szakály, M.; Kontor, E. A vásárlói magatartás elemzése az élelmiszer- és üzletválasztást befolyásoló tényezők alapján. Mark. Menedzsment 2020, 54,7-17. [CrossRef]

62. Hcso, T.S. Time Series of Annual Data-Population, Vital Events/1.2.Population by Type of Settlement, 1 January (1980-2019), 1.3.Population by Sex and Age, 1 January (1980-2019); Hungarian Central Statistical Office: Budapest, Hungary, 2019.

63. Hcso, T.S. Time Series of Annual, Regional Statistics—Population, Vital Events/6.1.1.Resident Population by Sex, 1 January (2001-2018); Hungarian Central Statistical Office: Budapest, Hungary, 2019.

64. Cronbach, L.J. Coefficient alpha and the internal structure of tests. Psychometrika 1951, 16, 297-334. [CrossRef]

65. Brunner, M.; Sü $\beta$, H.-M. Analyzing the reliability of multidimensional measures: An example from intelligence research. Educ. Psychol. Meas. 2005, 65, 227-240. [CrossRef]

66. Eit-Food. COVID-19 Impact on Consumer Food Behaviours in Europe. 2020. Available online: https: / / www.eitfood.eu/news/ post/eit-food-reportreveals-lasting-impact-of-covid-19-pandemic-on-european-food-behaviours (accessed on 17 March 2021).

67. IFIC. 2021 Food \& Health Survey: Pandemic Food Habits Start to Wane While Positive Approaches to Diet and Health Grow. 2021. Available online: https://www.globenewswire.com/news-release/2021/05/19/2232648/0/en/2021-Food-Health-SurveyPandemic-Food-Habits-Start-to-Wane-While-Positive-Approaches-to-Diet-and-Health-Grow.html (accessed on 10 June 2021).

68. Hobbs, J.E. Food supply chains during the COVID-19 pandemic. Can. J. Agric. Econ. Rev. Can. D'agroeconomie 2020, 68, 171-176 [CrossRef]

69. Cranfield, J.; Henson, S.; Blandon, J. The Effect of Attitudinal and Sociodemographic Factors on the Likelihood of Buying Locally Produced Food. Agribusiness 2012, 28, 205-221. [CrossRef]

70. Kiss, M.; Szakály, Z. Miért esszük azt, amit eszünk? A magyar fogyasztók étkezési motivációi. (Why do we eat what we eat? Eating motivations of Hungarian consumers.) In Post-Traumatic Marketing: Virtuality and Reality, Proceedings of the EMOK 2021 International Conference; Mitev, A., Csordás, T., Horváth, D., Boros, K., Eds.; Corvinus University of Budapest: Budapest, Hungary, 2021; pp. 388-398. ISBN 9789635038.

71. Szakály, Z. Trends and tendencies in the functional food market: What does the domestic consumer expect? Élelmiszer Táplálkozás és Mark. 2008, 5, 3-11. 